\title{
319. Wiederherstellungsoperationen und Re-Eingriffe nach mißglückten Osteosynthesen unter besonderer Berücksichtigung der Infektionen
}

\author{
W. Sat'tel*, D. Lattermann und H. Kämmerer-Göttingen \\ Reconstructive Operations and Re-Operations after Failed \\ Osteosynthesis, with Special Consideration of Infection
}

Summary. Plare fracture and posttraumatic osteomyelitis are among the most dreaded complications of operative fracture treatment. Whereas plate fractures can mostly be explained by inadequate biomechanics, the main causes of posttraumatic osteomyelitis are the relation of the number of organisms to the defence condition of the patient, mistakes in asepsis, severe traumatisation of soft tissues with resulting tissue hypoxia, and insufficient instruments. Despite repeated intervention with radical removal of infected parts and of all bone sequesters, establishment of wash-out and suction drainage and insertion of autologous spongious bone, there frequently occur therapeutic failures, especially marked in the form of Girdlestone's hip. Apart from observing the general rules in re-intervention, it is necessary to take into account the patient's age and general condition as well as the type, extent and failure of the primary osteosynthesis. The clinical and operative problems are discussed on 3 examples selected from the Göttingen material. Two further cases finally show how much simpler and more promising is operative treatment in cases of plate fracture when the bone is not infected.

Zusammenfassung. Plattenfraktur und posttraumatische Osteomyelitis gehören zu den gefürchtetsten Komplikationen operativer Frakturbehandlung. Während Plattenfrakturen meist durch unzureichende Biomechanik erklärt werden können, gehören die Beziehung Keimzahl-Abwehrlage des Patienten, Fehler in der Asepsis, starke Traumatisierung der Weichteile und daraus resultierende Gewebshypoxie sowie mangelhaftes Instrumentarium zu den Hauptgründen posttraumatischer Osteomyelitiden. Trotz wiederholter Eingriffe mit radikaler Infektausräumung, Entfernung aller Knochensequester, Anlegen einer Spül-Saugdrainage und Einbringen autologer Spongiosa entstehen häufig therapeutische Mißerfolge, wie sie als Girdlestone-Hüfte und Hüftkopfvarisierung besonders eindrucksvoll sind. Neben der Beachtung allgemeiner Gesichtspunkte sind bei Re-Interventionen Alter und körperlicher Allgemeinzustand des Patienten sowie Art, Umfang und Mißerfolg der Primärosteosynthese zu berücksichtigen.

Bei einer Auswahl des Göttinger Krankengutes erfolgt an 3 Beispielen die Besprechung dieser klinischen und operativen Problematik.

Weitere 2 Fälle von Re-Osteosynthesen zeigen abschließend, wieviel einfacher und erfolgversprechender sich die operative Behandlung am nicht infizierten Knochen bei Plattenfrakturen gestaltet. 